\title{
KEPROSPEKAN PANAS BUMI GUNUNG LAWU BERDASARKAN KAJIAN VULKANOSTRATIGRAFI
}

\author{
GEOTHERMAL PROSPECT OF MOUNT LAWU \\ BASED ON VOLCANOSTRATIGRAPHIC ANALYSIS
}

\author{
Dudi Hermawan dan Lano Adhitya Permana \\ Pusat Sumber Daya Mineral Batubara dan Panas Bumi \\ dudi.hermawan@esdm.go.id
}

\begin{abstract}
ABSTRAK
Gunung Lawu merupakan salah satu kerucut gunungapi di Indonesia yang memiliki keterdapatan manifestasi panas bumi dengan sebaran cukup luas di bagian lerengnya. Untuk mengetahui keprospekan panas bumi daerah Gunung Lawu diperlukan suatu kajian ilmiah yang bisa menjelaskan hubungan antara vulkanisme Gunung Lawu dengan pembentukan sistem panas bumi daerah tersebut. Metode penelitian dalam makalah ini adalah berupa kajian vulkanostratigrafi. Kajian dilakukan dengan menentukan parameter-parameter karakteristik vulkanik Gunung Lawu yang meliputi volume dan pola struktur geologi sebagai data primer, serta umur vulkanisme dan evolusi magma sebagai data sekunder. Hasil kajian menunjukkan bahwa Gunung Lawu memiliki volume gunungapi sebesar $300 \mathrm{~km}^{3}$ yang mengindikasikan keberadaan dapur magma yang cukup besar sebagai sumber panas, dengan vulkanisme termuda berumur 200 ribu tahun yang berada di kisaran umur ideal untuk membentuk sistem panas bumi yang matang. Pola struktur geologi menunjukkan arah struktur yang homogen dengan penyebaran vent radial mengarah ke puncak Gunung Lawu. Intensitas kerapatan patahan dan rekahan tinggi yang mencerminkan adanya zona permeabilitas tinggi terletak di lereng selatan dan barat Gunung Lawu. Dengan karakteristik tersebut, dapat disimpulkan bahwa daerah panas bumi Gunung Lawu memiliki prospek panas bumi yang menarik untuk dikembangkan dan perlu diteliti lebih lanjut, terutama pada lereng selatan dan barat Gunung Lawu.
\end{abstract}

Kata kunci: Gunung Lawu, vulkanisme, vulkanostratigrafi, sistem panas bumi, prospek

\section{ABSTRACT}

Mount Lawu is one of the volcanic cones in Indonesia which has geothermal manifestation with a fairly wide distribution on the slopes. To find out the geothermal prospect of the Gunung Lawu area, a scientific study is needed that can explain the relationship between Mount Lawu volcanism and the formation of its geothermal system. The research method carried out in this paper is volcanostratigraphic study. The study was conducted by determining the parameters of volcanic characteristics of Mount Lawu which include the volume and pattern of geological structures as primary data, as well as the age of volcanism and evolution of magma as secondary data. The results of the study show that Mount Lawu has volcanic volume of 300 $\mathrm{km}^{3}$ which indicates the presence of quite large magma chamber as heat source, with the youngest volcanism of 200 thousand years as the ideal age range to form mature geothermal system. The pattern of geological structure shows homogeneous structure direction with radial vent spread towards the peak of Mount Lawu. The high intensity of fault and fracture density which reflect the presence of high permeability zones are located on the southern and western slopes of Mount Lawu. With these characteristics, it can be concluded that the Gunung Lawu geothermal area has attractive geothermal prospect to be developed and needs further investigation, especially on the southern and western slopes of Mount Lawu.

Keywords: Mount Lawu, volcanism, volcanostratigraphy, geothermal system, prospect 


\section{MAKALAH ILMIAH}

\section{PENDAHULUAN}

Pulau Jawa merupakan salah satu pulau di Indonesia yang teletak pada zona pertemuan lempeng Indo-Australia dengan lempeng Eurasia. Pertemuan kedua lempeng tersebut mengakibatkan terjadinya aktivitas magmatik yang membentuk jalur gunungapi dari bagian barat sampai timur Pulau Jawa.

Aktivitas magmatik berperan dalam pembentukan sistem panas bumi sebagai sumber panas (heat source) yang memanasi air di kedalaman sehingga membentuk fluida panas di reservoir. Sumintadireja (2005) menyebutkan bahwa sistem panas bumi bertemperatur tinggi teletak di sepanjang zona vulkanik punggungan pemekaran benua, di atas zona subduksi, dan di daerah anomali pelelehan dalam lempeng. Batas-batas pertemuan lempeng yang bergerak merupakan pusat lokasi kemunculan sistem hidrotermal magma. Salah satu hasil aktivitas magmatik di Pulau Jawa adalah pembentukan kerucut gunungapi Lawu.

Gunung Lawu merupakan suatu kerucut gunungapi yang terletak di perbatasan Provinsi Jawa Tengah dan Jawa Timur. Pada lingkungan Gunung Lawu terdapat sejumlah pemunculan manifestasi panas bumi seperti fumarol, mata air panas, dan batuan ubahan yang mengindikasikan adanya suatu sistem panas bumi di kedalaman.

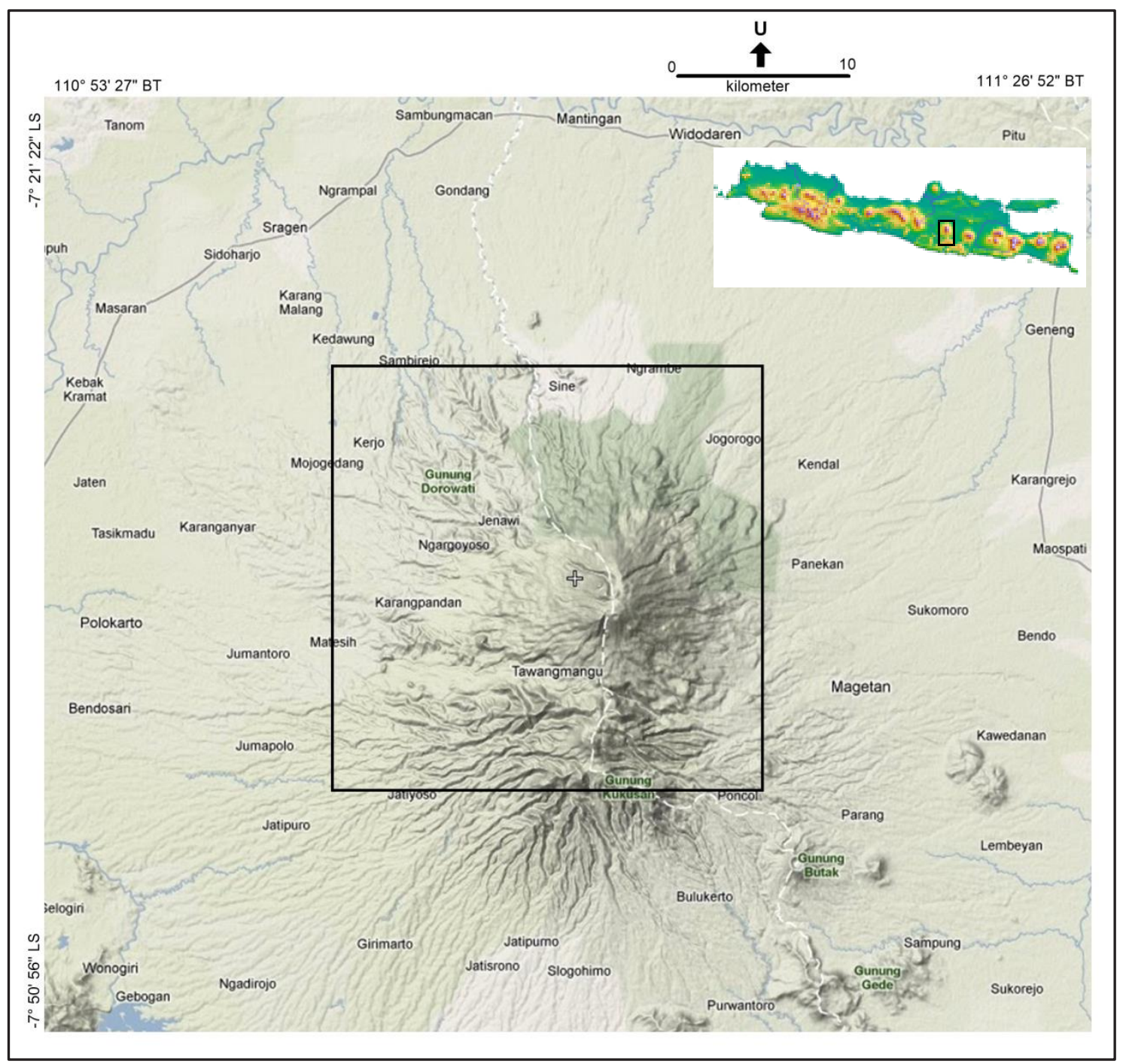

Gambar 1. Peta lokasi daerah panas bumi Gunung Lawu 
Untuk memahami bagaimana hubungan antara aktivitas vulkanik Gunung Lawu dengan pembentukan sistem panas buminya, maka perlu dilakukan studi atau kajian vulkanostratigrafi sehingga karakteristik vulkanik Gunung Lawu dapat diketahui dan dipahami, untuk nantinya dapat digunakan sebagai data teknis dalam pengembangan panas bumi daerah tersebut.

Davis (1973, dalam Wohletz \& Heiken, 1992) menyatakan bahwa terdapat beberapa data geologi yang bisa dianalisis untuk mengetahui hubungan antara karakteristik vulkanik suatu gunungapi dengan pembentukan sistem panas bumi. Data tersebut antara lain; analisis topografi dan sebaran satuan stratigrafi gunungapi, pola struktur geologi, umur relatif batuan, sebaran manifestasi panas bumi, dan analisis data geokimia.

Makalah ini akan membahas bagaimana karakteristik vulkanik Gunung Lawu dalam penentuan keprospekan panas bumi, sehingga diharapkan dapat memberikan rekomendasi untuk pengembangan selanjutnya.

\section{METODOLOGI}

Metodologi yang digunakan dalam kajian ini meliputi studi vulkanostratigrafi untuk mengetahui karakteristik vulkanik Gunung Lawu dan pola struktur geologi yang terbentuk, dengan mengikuti konsep eksplorasi panas bumi berdasarkan Wohletz \& Heiken (1992) seperti disajikan dalam Gambar 2.

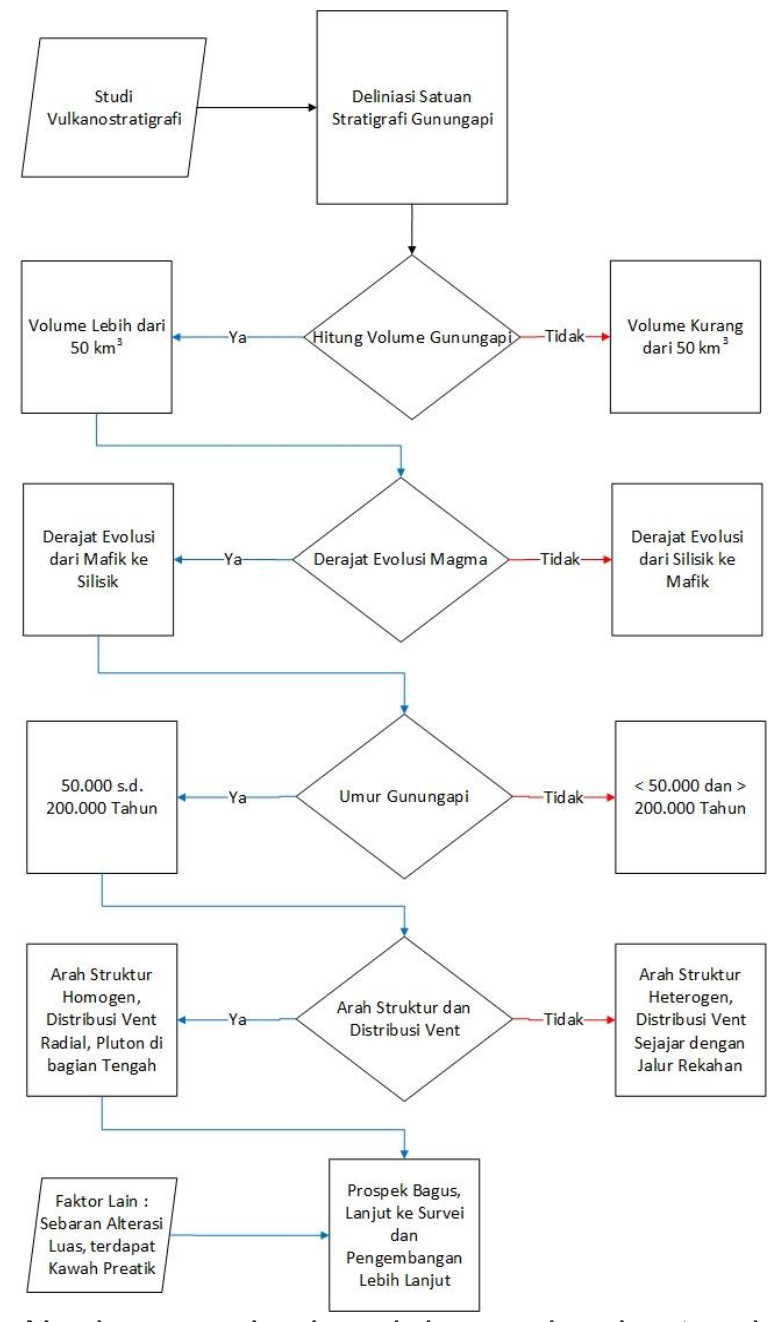

Gambar 2. Alur konsep eksplorasi dan evaluasi potensi panas bumi (modifikasi dari Wohletz \& Heiken, 1992) 
Dari Gambar 2 tersebut dapat dilihat bahwa parameter karakteristik gunungapi yang perlu untuk diketahui meliputi; sebaran atau distribusi batuan gunungapi berdasarkan dari sumber erupsinya, volume atau ukuran dari gunungapi, derajat evolusi dari komposisi magma pembentuk aktivitas vulkanik tersebut, umur vulkanisme termuda, dan pola struktur geologi yang terbentuk.

Kajian dilakukan dengan menentukan parameter-parameter karakteristik vulkanik Gunung Lawu yang meliputi sebaran atau distribusi batuan gunungapi, volume dan pola struktur geologi sebagai data primer, serta umur vulkanisme dan evolusi magma sebagai data sekunder.

Penentuan sebaran atau distribusi batuan gunungapi, dilakukan berdasarkan identifikasi satuan stratigrafi yang setara formasi yaitu khuluk dan satuan yang lebih kecil yaitu gumuk (Alessandro, dkk., 2013). Sandi Stratigrafi Indonesia Tahun 1996 menyatakan bahwa Khuluk gunungapi merupakan kumpulan batuan/ endapan yang dihasilkan oleh satu atau lebih titik erupsi yang membentuk satu tubuh gunungapi, sedangkan Gumuk gunungapi adalah bagian dari Khuluk yang terbentuk dari hasil suatu erupsi pada tubuh gunungapi tersebut, baik sebagai hasil erupsi pusat maupun erupsi samping. Identifikasi khuluk dan gumuk ini dilakukan pada peta topografi Bakosurtanal skala 1:25.000 Lembar Karangpandan, Ponco, Rambe dan Tawang Mangu.

Langkah pertama dalam mendelineasi satuan stratigrafi gunungapi adalah mengidentifikasi puncak tertinggi yang ditandai dengan struktur sirkular yang menunjukkan depresi kepundan, kaldera atau kawah untuk menentukan pusat erupsi utama ataupun sekunder. Pusat erupsi menjadi hal yang harus dikenali karena dengan demikian dapat diperkirakan ke mana arah penyebaran masing masing produk erupsi. Selanjutnya dilakukan analisis pola aliran sungai pada pola topografi yang menjorok ke arah pusat erupsi. Hal ini dilakukan untuk mendapatkan gambaran umum pola struktur yang berkembang di daerah kajian berdasarkan analisis morfologi. Setelah analisis pola aliran sungai, kemudian dilakukan analisis kelurusan punggungan yang ditandai dengan pola topografi yang menjauh dari pusat erupsi untuk melihat morfologi perbukitan.

Penentuan khuluk pada makalah ini dilakukan berdasarkan pola kontur dari kerucut gunung api yang berukuran besar dan terkenal di Indonesia. Sedangkan penentuan satuan gumuk dilakukan berdasarkan pola kontur kerucut gunung api yang berukuran kecil dan berada di sekitar khuluk. Khuluk dan gumuk yang telah teridentifikasi, dipisahkan berdasarkan batas vulkanostratigrafi yaitu ketika populasi punggungan dan aliran sungai membentuk pola radial, maka dianggap berasal dari satu sumber yang sama (Van Zuidam, 1985).

Luas dari masing-masing khuluk yang telah teridentifikasi dan diketahui ketinggiannya, dapat digunakan untuk menghitung volume gunungapi dengan asumsi bentuk gunungapi berupa kerucut. Penghitungannya adalah dengan menggunakan rumus $1 / 3 \times A \times h$, dimana $A$ adalah luas alas gunung, dan $h$ adalah tinggi (selisih antara elevasi puncak gunung dengan elevasi terendah gunung). Khuluk dengan volume $>50 \mathrm{~km}^{3}$ menunjukkan bahwa khuluk tersebut kemungkinan memiliki dapur magma yang cukup besar, dan bisa berperan sebagai sumber panas dalam suatu sistem panas bumi (Wohletz \& Heiken, 1992).

Derajat evolusi magma dan umur vulkanisme diketahui dari data terdahulu berdasarkan penelitian Badan Geologi tahun 2009, yang telah melakukan pemetaan geologi rinci di daerah panas bumi Gunung Lawu.

Pola struktur geologi dan distribusi vent dibuat melalui analisis kelurusan pada citra Digital Elevation Model (DEM) (Gambar 3). Hung et al., (2005) menyatakan bahwa suatu kelurusan dapat berupa aliran yang 
lurus dan lembah, permukaan yang lurus, perubahan tonal tanah, kelurusan daerah vegetasi, perubahan dari perbedaan tipe vegetasi dan ketinggiannya, atau perbedaan topografi yang kontras. Semua fenomena ini kemungkinan hasil dari fenomena struktur, seperti; sesar (patahan), kekar, lipatan dan rekahan.

Pada penelitian ini kelurusan ditarik berdasarkan kesamaan pola pada citra DEM secara manual berupa garis. Pola yang dimaksud adalah susunan yang teratur mengenai kenampakan geologi, topografi dan vegetasi (Ray, 1960 dalam
Soetoto, 1996). Misalnya pola garis lurus menunjukkan adanya kekar, sesar, dan ketidakselarasan. Arah dari kelurusan ini kemudian diklasifikasikan ke dalam arah umum kelurusan pada diagram Roset, sehingga diketahui arah umum dari kelurusan atau struktur geologi yang terbentuk (Hermawan dan Rezky, 2011). Setelah itu dilakukan penghitungan panjang kelurusan tiap $1 \mathrm{~km}^{2}$ untuk mendapatkan peta kerapatan patahan dan rekahan (fault and fracture density map), dengan unit yang diperoleh adalah $\mathrm{km} / \mathrm{km}^{2}$ (Soengkono, 1999).

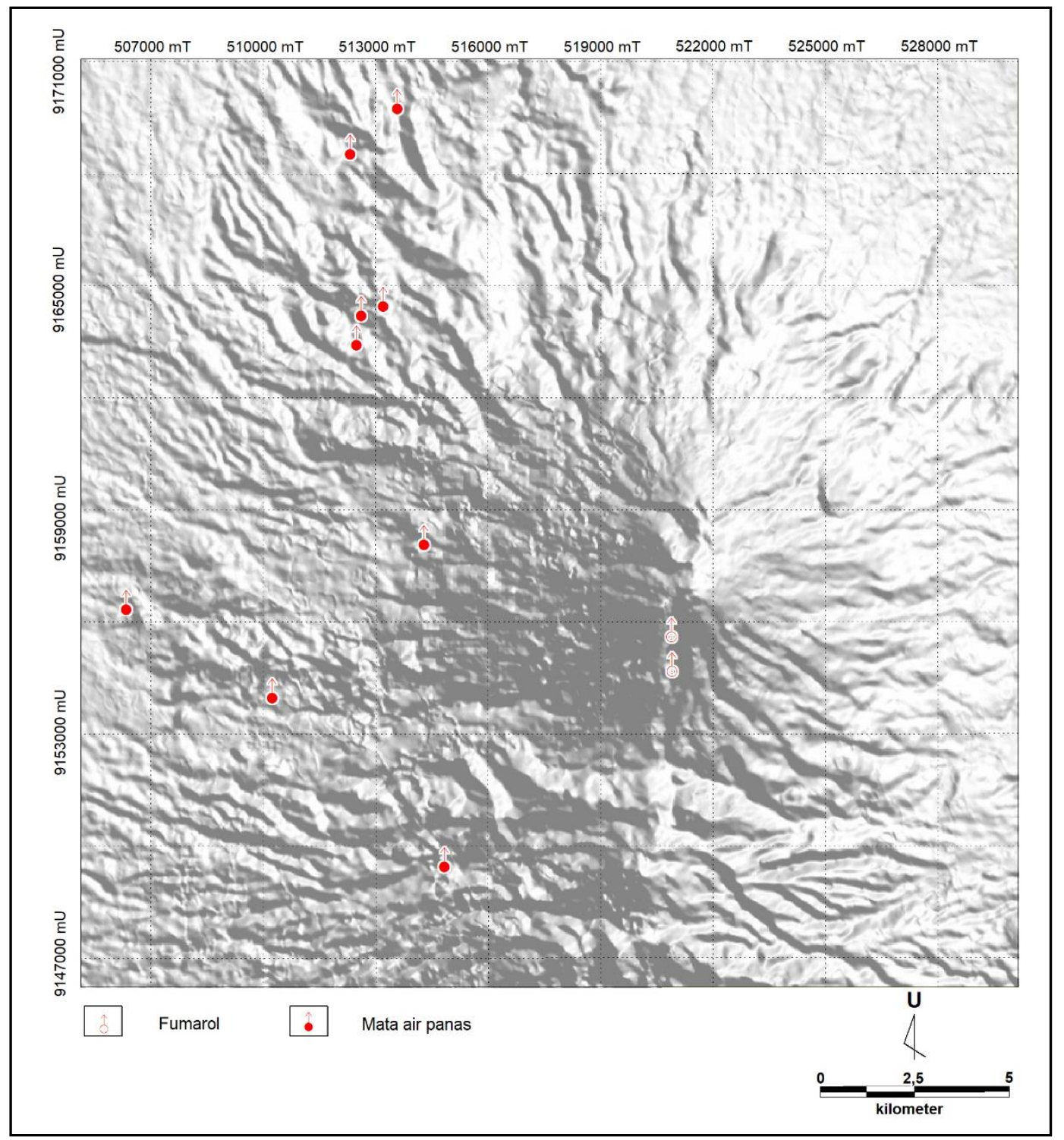

Gambar 3. Citra DEM resolusi 90m daerah panas bumi Gunung Lawu (http://srtm.csi.cgiar.org) 


\section{GEOLOGI GUNUNG LAWU}

Hasil pemetaan geologi di daerah panas bumi Gunung Lawu yang dilakukan oleh Anonim (2009) menyebutkan bahwa batuan tertua yang ada di daerah kajian adalah batulempung berumur Miosen Awal. Pada Kala Miosen Tengah terjadi aktivitas magmatik yang membentuk batuan intrusi berkomposisi andesit. Kemudian pada Kala Miosen Akhir-Pliosen terjadi proses sedimentasi yang menyebabkan terbentuknya satuan batugamping. Aktivitas tektonik regional pada Kala Pliosen-Plistosen memicu terjadinya kegiatan vulkanik yang membentuk batuan vulkanik Gunung Jobolarangan (Lawu Tua) yang terdiri dari lava berkomposisi andesit-basaltik dan batuan piroklastik yang bersifat asam (silisik). Selanjutnya aktivitas vulkanik berpindah ke sebelah utara yang ditandai dengan pembentukan batuan vulkanik Gunung Lawu Muda berkomposisi andesitbasaltik yang membentuk morfologi Gunung Lawu sekarang. Setelah fase erupsi Gunung Lawu yang membentuk batuan piroklastik, aktivitas vulkanik Gunung Lawu berakhir dengan pembentukan kubah lava muda berkomposisi andesit-basaltik di puncak Gunung Lawu dan kerucut-kerucut Gunung Purung dan Gunung Anak berkomposisi andesit yang merupakan produk erupsi samping. Proses erosi yang berlangsung sampai saat ini menghasilkan endapan lahar dan aluvium seperti yang banyak terdapat di sepanjang pedataran dan sungai-sungai besar. Manifestasi di daerah panas bumi Gunung Lawu muncul di lereng selatan berupa fumarol dan mata air panas dengan temperatur sekitar $90^{\circ} \mathrm{C}$, serta batuan ubahan bertipe argilik hingga argilik lanjut, dan tersebar luas di kaki barat dan baratlaut Gunung Lawu berupa mata air panas dengan temperatur $32^{\circ} \mathrm{C}$ hingga $40^{\circ} \mathrm{C}$.

\section{HASIL ANALISIS}

Dari peta vulkanostratigrafi daerah panas bumi Gunung Lawu (Gambar 4), dapat dilihat bahwa terdapat tiga bentukan topografi kawah yaitu satu di puncak Gunung Lawu dan dua kawah di puncak Gunung Jobolarangan. Bentukan kawah ini dapat diperkirakan sebagai pusat erupsi utama dari aktivitas vulkanik yang terjadi di daerah kajian. Dari bentukan kawah ini dapat diperkirakan adanya dua pusat vulkanisme yang berbeda, yaitu vulkanisme Lawu dan vulkanisme Jobolarangan. Hal ini sesuai dengan hasil pemetaan Anonim (2009) yang menyatakan bahwa secara umum terdapat dua periode vulkanisme yang berbeda, yaitu vulkanisme Jobolarangan (Lawu Tua) dan vulkanisme Lawu Muda.

Hasil delineasi satuan stratigrafi vulkanik menunjukkan bahwa daerah kajian disusun oleh dua khuluk, yaitu Khuluk Jobolarangan dan Khuluk Lawu.

Khuluk Lawu tersebar di bagian utara, barat, timur, sampai tengah dengan luas sebaran sekitar $75 \%$ dari luas daerah kajian. Pola aliran sungai pada Khuluk Lawu ini umumnya berpola radial mengarah ke puncak Gunung Lawu. Di dalam Khuluk Lawu teridentifikasi beberapa bentukan gumuk yaitu Gumuk Purung, Gumuk Pablengan, Gumuk Kemuning, Gumuk Kresno, Gumuk Sidomukti, dan Gumuk Anak.

Gumuk Purung terletak di sebelah baratdaya lereng Gunung Lawu dengan pola kontur membentuk suatu topografi kerucut soliter. Apabila disebandingkan dengan Peta Geologi Daerah Panas Bumi Gunung Lawu (Anonim, 2009), Gumuk Purung ini disusun oleh batuan lava andesit Gunung Purung yang merupakan produk dari erupsi samping.

Gumuk Pablengan terletak di sebelah baratdaya Khuluk Lawu atau di sebelah barat Gumuk Purung dengan pola kontur membentuk perbukitan memanjang di daerah sekitar Pablengan. Apabila disebandingkan dengan Peta Geologi Daerah Panas Bumi Gunung Lawu (Anonim, 2009), Gumuk Pablengan ini disusun oleh batuan piroklastik tua produk dari Gunung Jobolarangan. Pada Gumuk 
Pablengan terdapat pemunculan manifestasi panas bumi berupa mata air panas Pablengan dengan temperatur $36^{\circ} \mathrm{C}$.

Gumuk Kemuning terletak di sebelah barat lereng Gunung Lawu yang diidentifikasi berdasarkan adanya pola kontur yang memanjang membentuk suatu perbukitan soliter. Apabila disebandingkan dengan Peta Geologi Daerah Panas Bumi Gunung Lawu (Anonim, 2009), Gumuk Kemuning ini disusun oleh batuan lava basalt Ceto yang merupakan produk dari erupsi samping.

Gumuk Kresno terletak di sebelah barataut lereng Gunung Lawu yang diidentifikasi berdasarkan adanya pola kontur yang memanjang berarah baratlaut - tenggara. Apabila disebandingkan dengan Peta Geologi Daerah Panas Bumi Gunung Lawu (Anonim, 2009), Gumuk Kresno ini disusun oleh batuan aliran piroklastik Gunung Lawu. Pada Gumuk Kresno terdapat pemunculan manifestasi panas bumi berupa mata air panas Ngunut dan Jenawi dengan temperatur $32^{\circ} \mathrm{C}$ hingga $40^{\circ} \mathrm{C}$.

Gumuk Sidomukti terletak di sebelah timur Gumuk Kresno yang diidentifikasi berdasarkan adanya pola kontur yang memanjang berarah baratlaut-tenggara. Apabila disebandingkan dengan Peta Geologi Daerah Panas Bumi Gunung Lawu (Anonim, 2009), Gumuk Sidomukti ini disusun oleh batuan aliran piroklastik Gunung Lawu. Pada Gumuk Sidomukti terdapat pemunculan manifestasi panas bumi berupa mata air panas Bayanan dengan temperatur $40^{\circ} \mathrm{C}$.

Gumuk Anak terletak di sebelah timur lereng Gunung Lawu yang diidentifikasi berdasarkan adanya pola kontur yang memanjang berarah baratdaya-timurlaut. Apabila disebandingkan dengan Peta Geologi Daerah Panas Bumi Gunung Lawu (Anonim, 2009), Gumuk Anak ini disusun oleh batuan lava andesit Gunung Anak yang merupakan produk dari erupsi samping.

Di lereng selatan Khuluk Lawu terdapat pemunculan manifestasi panas bumi yang berupa fumarol dan mata air panas dengan temperatur sekitar $90^{\circ} \mathrm{C}$, serta batuan ubahan (Anonim, 2009).

Khuluk Jobolarangan terdapat di bagian selatan dengan luas sebaran sekitar $25 \%$ dari luas daerah kajian yang terdiri dari empat gumuk yaitu Gumuk Cemorowayang, Gumuk Sitatang, Gumuk Kukusan, dan Gumuk Mongkrang (Gambar 4). Pola aliran sungai pada Khuluk Jobolarangan ini di bagian puncak dan lereng umumnya berpola radial mengarah ke puncak Gunung Jobolarangan, sedangkan di bagian pedatarannya berpola dendritik sampai sub dendritik. Pada Khuluk Jobolarangan teridentifikasi dua bentukan kawah di bagian puncak Gunung Jobolarangan dan Gunung Mongkrang, yang diperkirakan merupakan pusat erupsi utama vulkanisme Gunung Jobolarangan. Kawah di puncak Gunung Mongkrang diperkirakan merupakan pusat erupsi dari vulkanisme Gunung Mongkrang yang membentuk Gumuk Mongkrang.

Gumuk Cemorowayang terletak di sebelah barataut lereng Gunung Jobolarangan yang diidentifikasi berdasarkan adanya pola kontur yang memanjang berarah barat-timur. Apabila disebandingkan dengan Peta Geologi Daerah Panas Bumi Gunung Lawu (Anonim, 2009), Gumuk Cemorowayang ini dominan disusun oleh batuan aliran piroklastik Gunung Jobolarangan. Pada Gumuk Cemorowayang terdapat pemunculan manifestasi panas bumi berupa mataair panas Tasin dengan temperatur sebesar $40^{\circ} \mathrm{C}$.

Gumuk Sitatang terletak di sebelah selatan lereng Gunung Jobolarangan yang diidentifikasi berdasarkan adanya pola kontur yang memanjang berarah baratdaya - timurlaut. Apabila disebandingkan dengan Peta Geologi Daerah Panas Bumi Gunung Lawu (Anonim, 2009), Gumuk Sitatang ini dominan disusun oleh batuan lava dan aliran piroklastik Gunung Jobolarangan.

Gumuk Kukusan terletak di sebelah selatan lereng Gunung Jobolarangan yang 
diidentifikasi berdasarkan adanya pola kontur yang memanjang berarah baratdaya - timurlaut. Apabila disebandingkan dengan Peta Geologi Daerah Panas Bumi Gunung Lawu (Anonim, 2009), Gumuk Kukusan ini dominan disusun oleh batuan lava dan aliran piroklastik Gunung Jobolarangan.

Gumuk Mongkrang terletak di sebelah utara dan timur lereng Gunung Jobolarangan yang diidentifikasi berdasarkan adanya pola kontur yang memanjang berarah barat-timur. Apabila disebandingkan dengan Peta Geologi Daerah Panas Bumi Gunung Lawu (Anonim, 2009), Gumuk Mongkrang ini dominan disusun oleh batuan aliran piroklastik Gunung Jobolarangan.

Dari peta vulkanostratigrafi daerah panas bumi Gunung Lawu (Gambar 4) dapat terlihat bahwa morfologi khuluk yang masih memperlihatkan suatu bentuk kerucut gunungapi yang relatif baik adalah Khuluk Lawu. Hal ini bisa dilihat dari morfologinya yang halus yang menunjukkan tingkat erosi yang belum intensif dengan pola aliran sungai yang masih terlihat jelas radial ke arah puncak. Bentuk kerucut yang relatif masih baik yang ditunjang dengan keterdapatan struktur sirkular yang merupakan bentuk kawah/kaldera di bagian puncak, menunjukkan bahwa di bawah Gunung Lawu kemungkinan terdapat magma chamber atau dapur magma yang berpotensi masih menyimpan panas yang dibutuhkan untuk membentuk suatu sistem panas bumi. Sedangkan morfologi Khuluk Jobolarangan menunjukkan suatu morfologi bentuk kerucut yang kasar, dikarenakan telah mengalami deformasi dan tingkat erosi yang intensif. Hal tersebut menunjukkan bahwa Khuluk Jobolarangan ini terbentuk lebih tua dibandingkan dengan Khuluk Lawu, sehingga dapur magma di bawah Gunung Jobolarangan diperkirakan telah mendingin dan kurang prospek untuk membentuk sistem panas bumi yang baik. Hal ini didukung oleh data sebaran pemunculan manifestasi panas bumi di permukaan, yang menunjukkan bahwa pemunculan manifestasi lebih intensif di Khuluk Lawu dibandingkan dengan di Khuluk Jobolarangan. Oleh karena itu dalam analisis dan pembahasan selanjutnya yang akan dibahas terbatas hanya pada Khuluk Lawu.

Hasil delineasi Khuluk Lawu menunjukkan diameter Khuluk sebesar 20 km (jari-jari 10 $\mathrm{km}$ ), dengan elevasi puncak tertinggi 3200 mdpl, dan elevasi terendah 200 m. Dari parameter-parameter tersebut, diperoleh ukuran atau volume Gunung Lawu sebesar $\pm 300 \mathrm{~km}^{3}$.

Pemetaan geologi yang dilakukan Badan Geologi tahun 2009 (Gambar 5), menunjukkan bahwa batuan vulkanik penyusun daerah kajian mengalami evolusi dari batuan vulkanik berkomposisi magma silisik ke arah mafik, dengan batuan termuda berupa kubah lava di puncak Gunung Lawu berkomposisi andesitbasaltik. Data pentarikhan umur batuan dengan metode pentarikhan radiometrik (Anonim, 2009), menunjukkan bahwa batuan vulkanik termuda berumur 0,2 $\pm 0,1$ juta tahun atau sekitar 200 ribu tahun.

Berdasarkan kesamaan pola pada citra DEM, ditarik garis-garis kelurusan yang menunjukkan perkiraan kelurusan patahan dan rekahan (Gambar 6). Garis-garis kelurusan ini kemudian dimasukkan ke dalam Diagram Roset (Gambar 7), untuk diklasifikasikan arah umum dari kelurusan tersebut. Dari Gambar 7 tersebut diketahui bahwa arah kelurusan yang terbentuk di daerah Gunung Lawu relatif homogen, dengan arah dominan baratlaut-tenggara (N 290\%/E). Distribusi atau sebaran vent relatif radial atau memusat ke arah puncak, sehingga diperkirakan dapur magma terdapat di bawah puncak Gunung Lawu. 


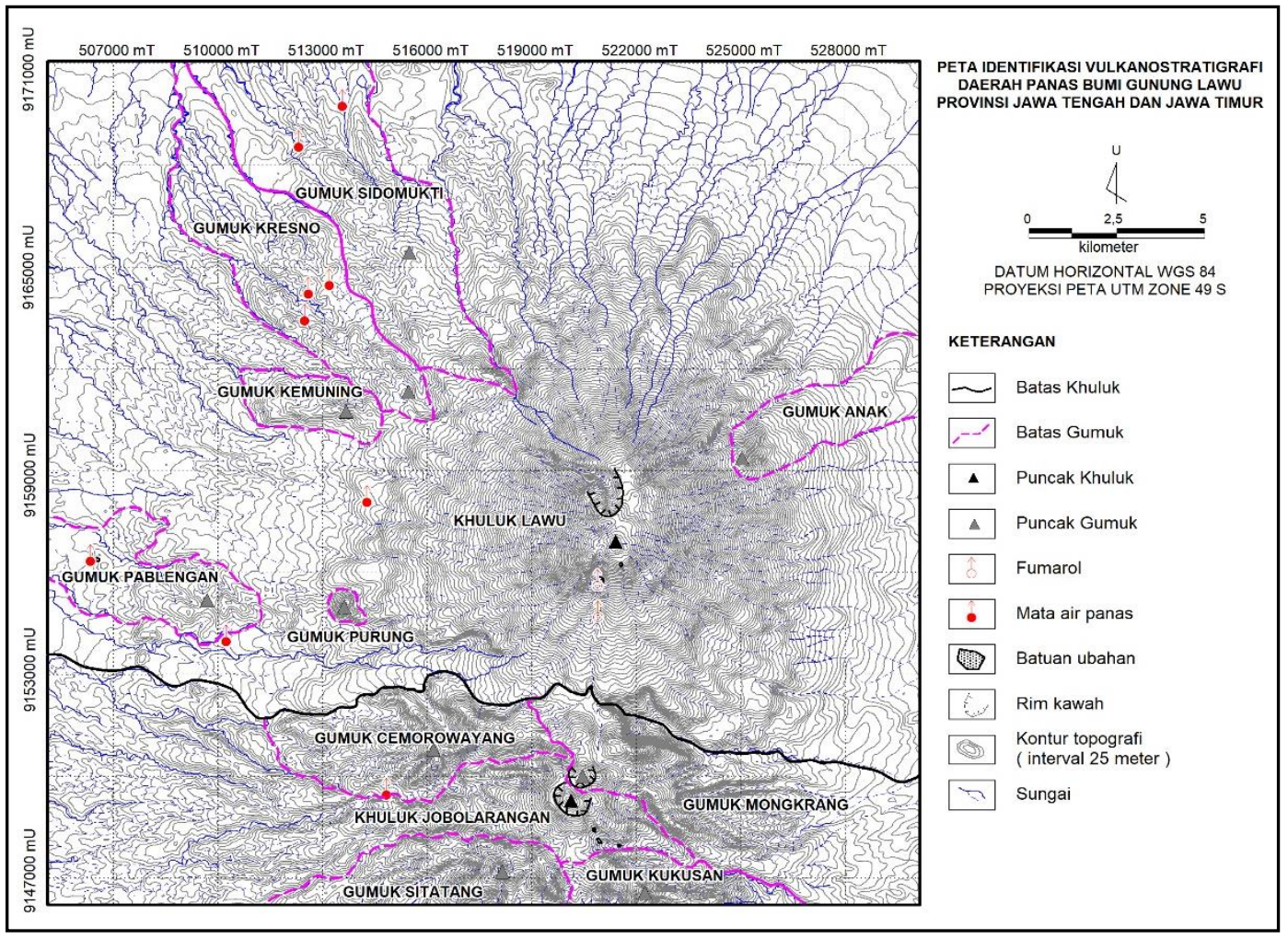

Gambar 4. Peta identifikasi vulkanostratigrafi daerah panas bumi Gunung Lawu

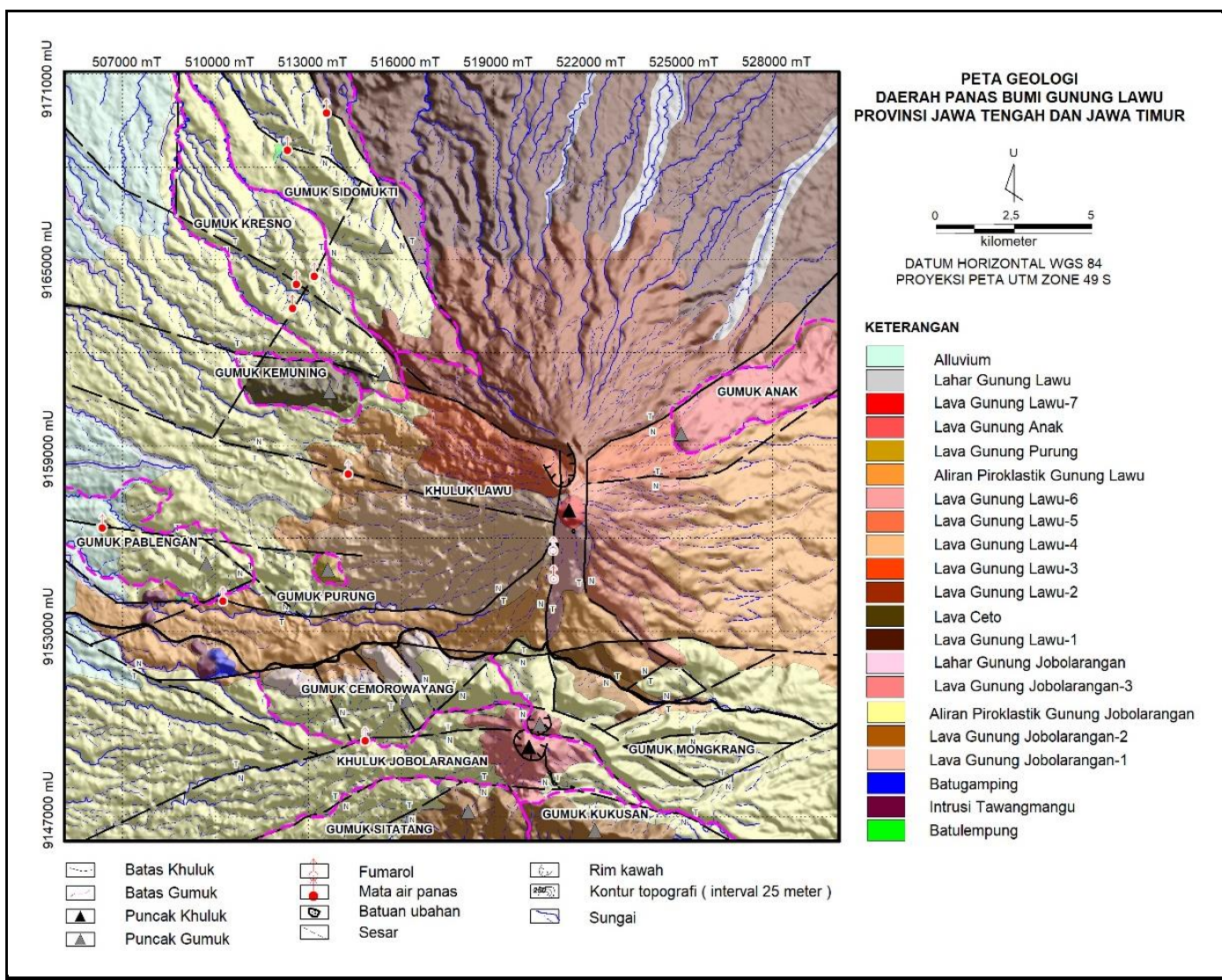

Gambar 5. Peta geologi daerah panas bumi Gunung Lawu (modifikasi dari Anonim, 2009) dikompilasikan dengan hasil identifikasi vulkanostratigrafi 


\section{MAKALAH ILMIAH}

Untuk mengetahui intensitas kerapatan patahan dan rekahan yang terbentuk, dilakukan penghitungan panjang kelurusan-kelurusan tersebut tiap $1 \mathrm{~km}^{2}$, sehingga menghasilkan peta kerapatan patahan dan rekahan (Gambar 8). Dari peta tersebut dapat dilihat bahwa intensitas tinggi kerapatan dan rekahan ditunjukkan oleh nilai kerapatan lebih besar dari 2,25 $\mathrm{km} / \mathrm{km}^{2}$, yang dominan tersebar di lereng selatan dan barat Gunung Lawu, terutama di sekitar pemunculan manifestasi panas bumi, sedangkan intensitas rendah sedang dengan nilai kerapatan kurang dari $2,25 \mathrm{~km} / \mathrm{km}^{2}$ tersebar di bagian utara dan timur daerah kajian.

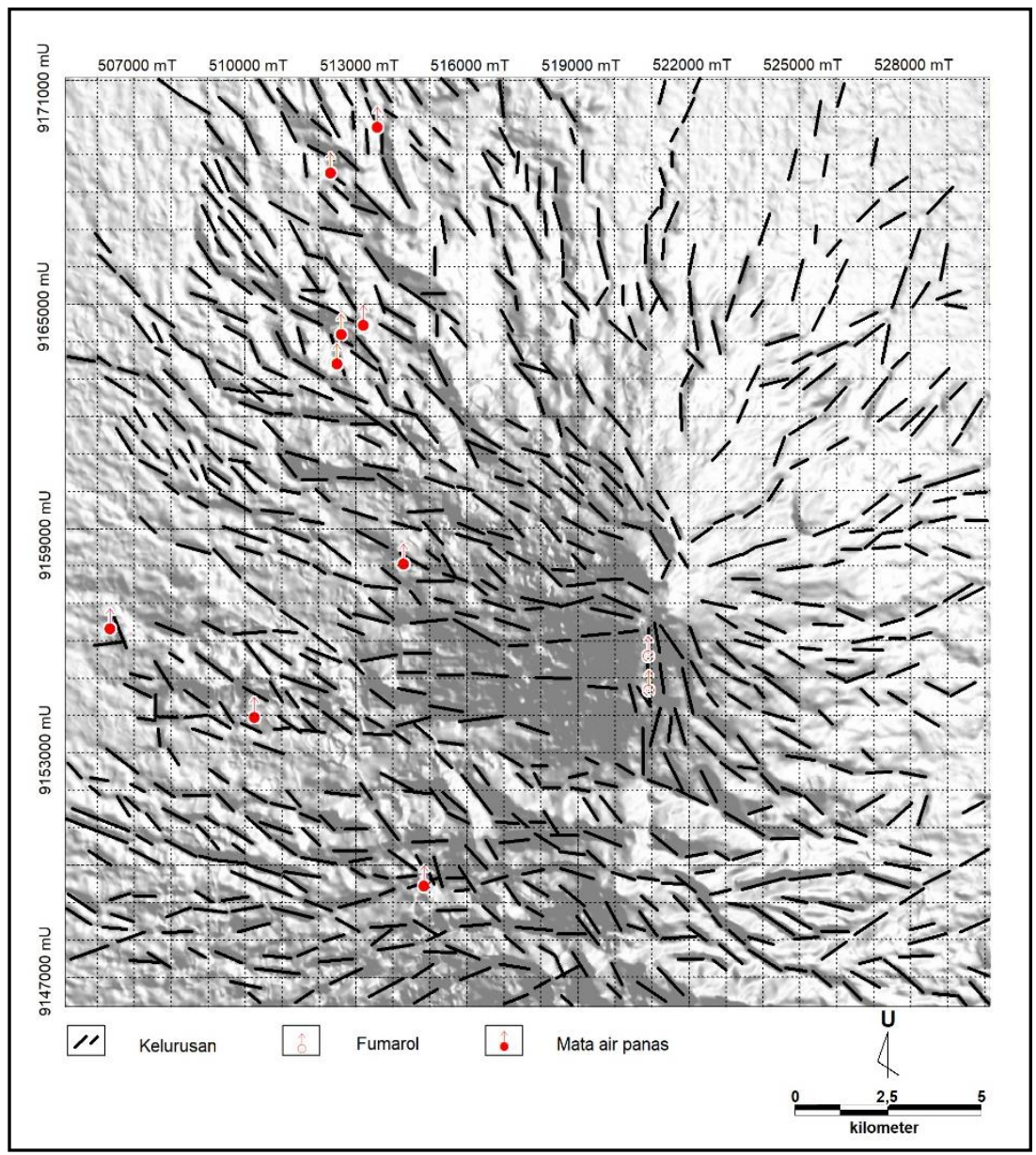

Gambar 6. Peta kelurusan daerah panas bumi Gunung Lawu

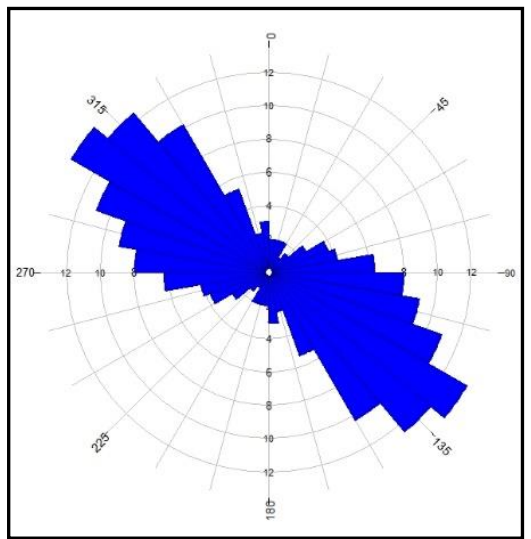

Gambar 7. Arah kelurusan di daerah panas bumi Gunung Lawu 


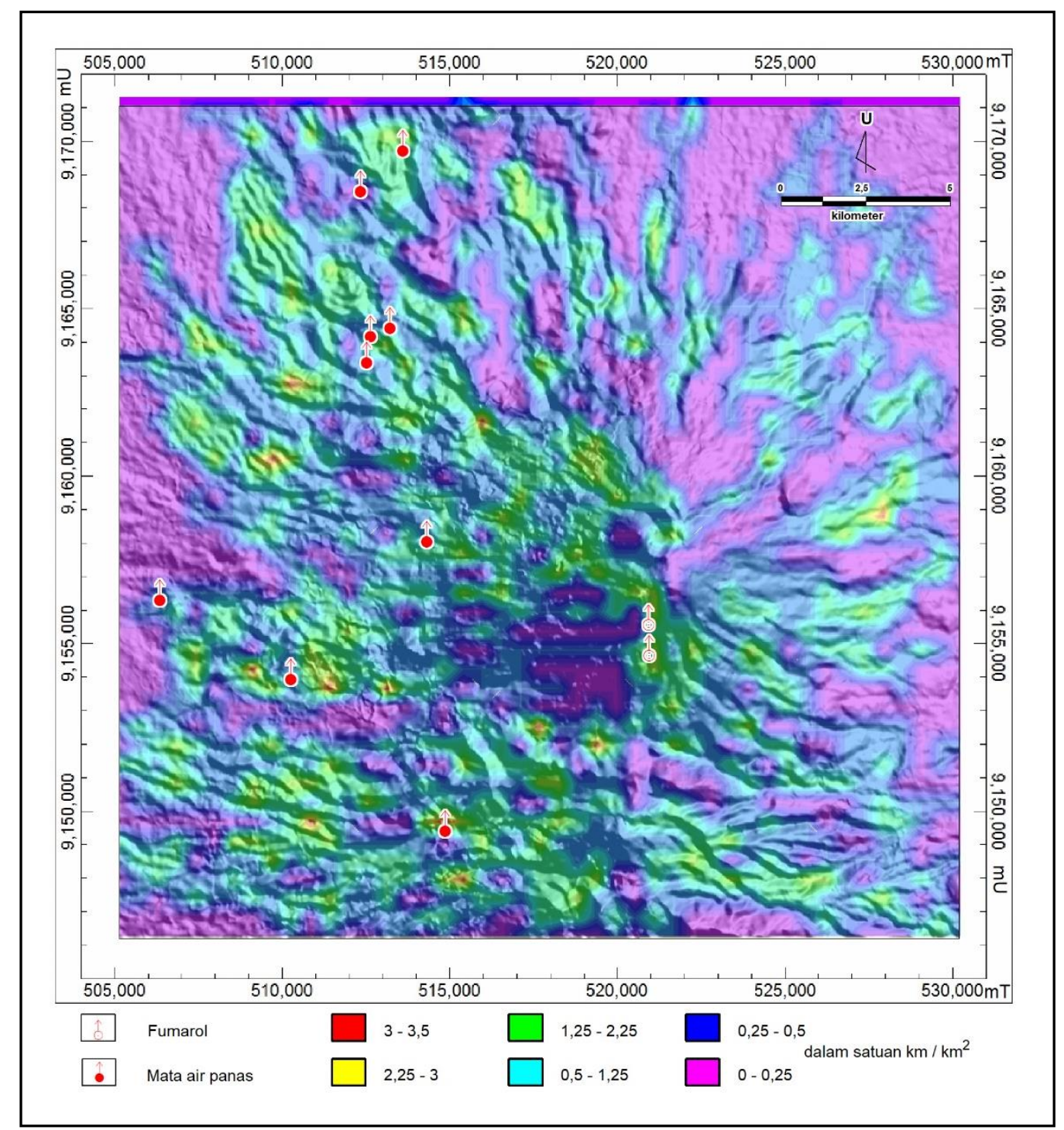

Gambar 8. Peta kerapatan patahan dan rekahan daerah panas bumi Gunung Lawu

\section{PEMBAHASAN}

Kajian vulkanostratigrafi (Gambar 9) menunjukkan Gunung Lawu memiliki dimensi atau volume gunungapi lebih besar dari $50 \mathrm{~km}^{3}$ (yaitu sebesar $300 \mathrm{~km}^{3}$ ), sehingga diperkirakan memiliki dapur magma cukup besar sebagai sumber panas yang menyuplai panas ke reservoir di kedalaman.

Hasil pemetaan geologi yang dilakukan Anonim (2009) menyatakan bahwa produk awal vulkanisme Gunung Lawu adalah berupa batuan lava dan piroklastik berkomposisi andesitik hingga silisik (asam), yang kemudian diakhiri dengan pembentukan kubah lava di puncak
Gunung Lawu berkomposisi andesitbasaltik. Hal ini menunjukkan bahwa telah terjadi evolusi magma pada vulkanisme Gunung Lawu, berupa perubahan komposisi magma dari bersifat silisik (asam) menuju mafik(andesitik). Komposisi batuan seperti ini umum ditemukan pada zona subduksi termasuk di Indonesia. Meskipun menurut Wohletz \& Heiken (1992) batuan dengan komposisi andesitik diasumsikan kurang prospek untuk pengembangan panas bumi, akan tetapi apabila vulkanismenya berada di zona subduksi pada tatanan aktif margin seperti Gunung Lawu ini, maka diperkirakan masih memiliki prospek yang baik. Sebagai contoh adalah vulkanisme Gunung Salak yang juga memiliki komposisi magma 


\section{MAKALAH ILMIAH}

andesitik yang sudah terbukti bisa membentuk lapangan panas bumi Awibengkok-Gunung Salak yang telah berproduksi (Hulen and Anderson, 1998).

Aktivitas vulkanik termuda Gunung Lawu memiliki umur yang masih cukup muda dan berada pada kisaran umur batuan ideal yaitu sekitar 200 ribu tahun (Anonim, 2009), yang diperkirakan masih menyimpan panas yang memadai untuk membentuk resevoir panas bumi bertemperatur tinggi, serta bisa menjaga keberlangsungan transfer atau perpindahan panas dari sumber panas ke reservoir untuk membentuk sistem panas bumi yang matang (mature).

Pola struktur geologi menunjukkan arah struktur yang homogen dengan distribusi vent radial yang mengindikasikan magmatisme berpusat di bawah kerucut termuda Gunung Lawu sehingga akumulasi panas dari heat source terkumpul di bagian tersebut. Intensitas kerapatan patahan dan rekahan tinggi yang tersebar di lereng barat dan selatan Gunung Lawu menunjukkan bahwa daerah tersebut memiliki permeabilitas tinggi yang berpotensi sebagai zona recharge atau discharge di permukaan, maupun sebagai zona reservoir di kedalaman.

Pemunculan manifestasi fumarol di lereng selatan Gunung Lawu menunjukkan adanya fluida reservoir di bawah manifestasi tersebut, yang kemudian mengalir secara lateral mengikuti elevasi membentuk manifestasi air panas di lereng barat Gunung Lawu (Gambar 10). Dari gambar tersebut dapat dilihat bahwa sumber panas berasal dari dapur magma di bawah kerucut Gunung Lawu. Fluida magmatik dan gas-gas vulkanik dari tubuh magma berinteraksi dengan air meteorik di kedalaman membentuk zona reservoir pada batuan permeabel. Fluida panas berupa uap dan gas naik ke permukaan sepanjang jalur rekahan membentuk manifestasi fumarol pada elevasi tinggi. Sedangkan fluida panas berupa air mengalir secara lateral mengikuti elevasi kemudian muncul di permukaan sebagai mata air panas pada kaki Gunung Lawu. Aliran lateral fluida panas yang hanya mengarah ke lereng barat Gunung Lawu menunjukkan bahwa lereng barat tersebut relatif memiliki permeabilitas yang lebih baik dibandingkan dengan bagian lereng yang lain. Hal ini didukung juga dengan sebaran vent yang lebih dominan di lereng bagian barat yang ditunjukkan oleh banyaknya bentukan satuan gumuk yang terbentuk di permukaan serta tingginya intensitas kerapatan patahan dan rekahan pada lereng barat tersebut.

Untuk mengetahui daerah yang memiliki prospek untuk dikembangkan, maka dilakukanlah kompilasi dari hasil identifikasi vulkanostratigrafi, pola struktur geologi, dan sebaran manifestasi panas bumi dalam bentuk peta kompilasi (Gambar 11). Dari peta tersebut dapat diketahui bahwa daerah yang memiliki prospek untuk dikembangkan dan diteliti lebih lanjut adalah di lereng selatan dan barat Gunung Lawu. 


\section{MAKALAH ILMIAH}

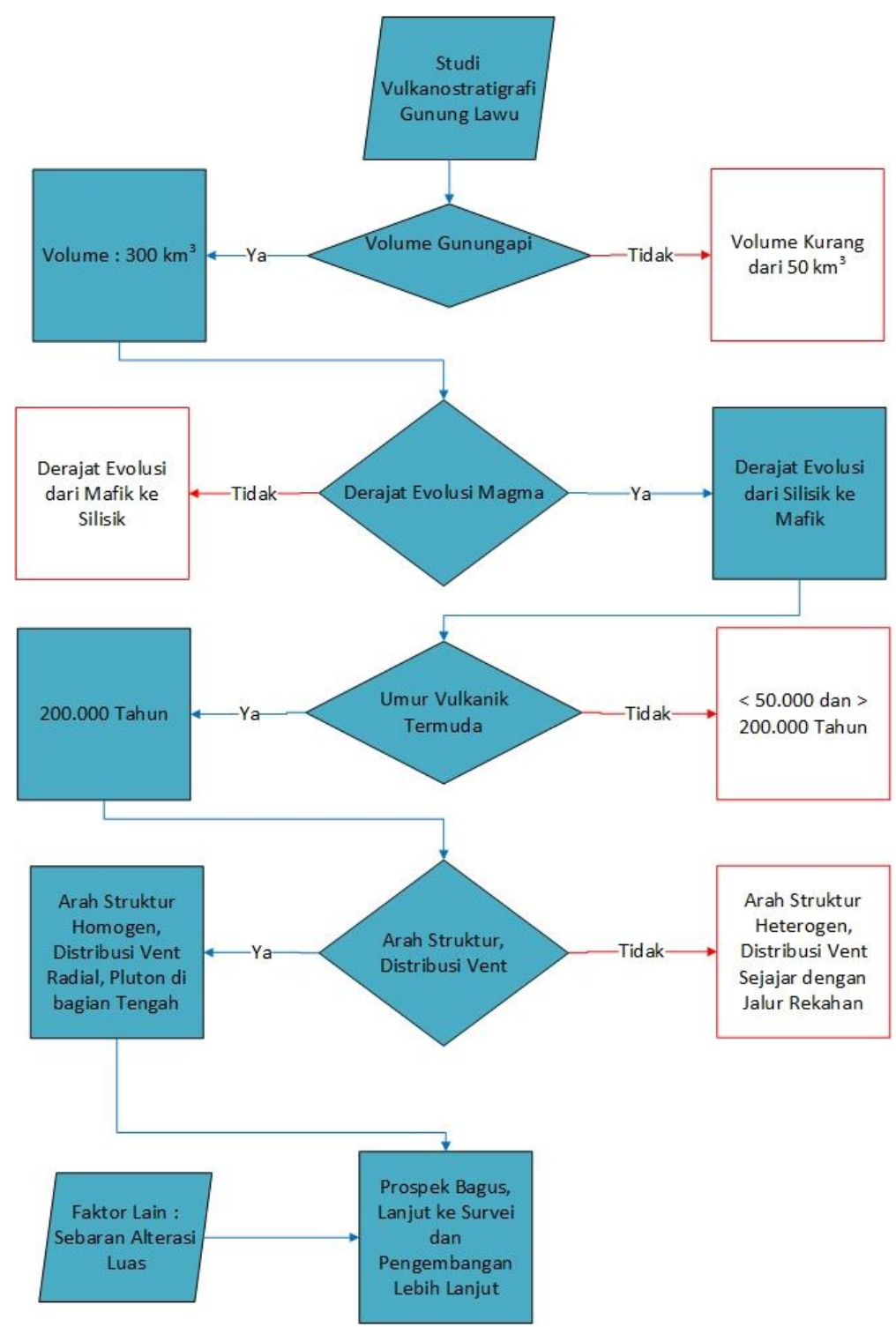

Gambar 9. Alur proses kajian vulkanostratigrafi Gunung Lawu berdasarkan konsep eksplorasi panas bumi (modifikasi dari Wohletz \& Heiken, 1992)

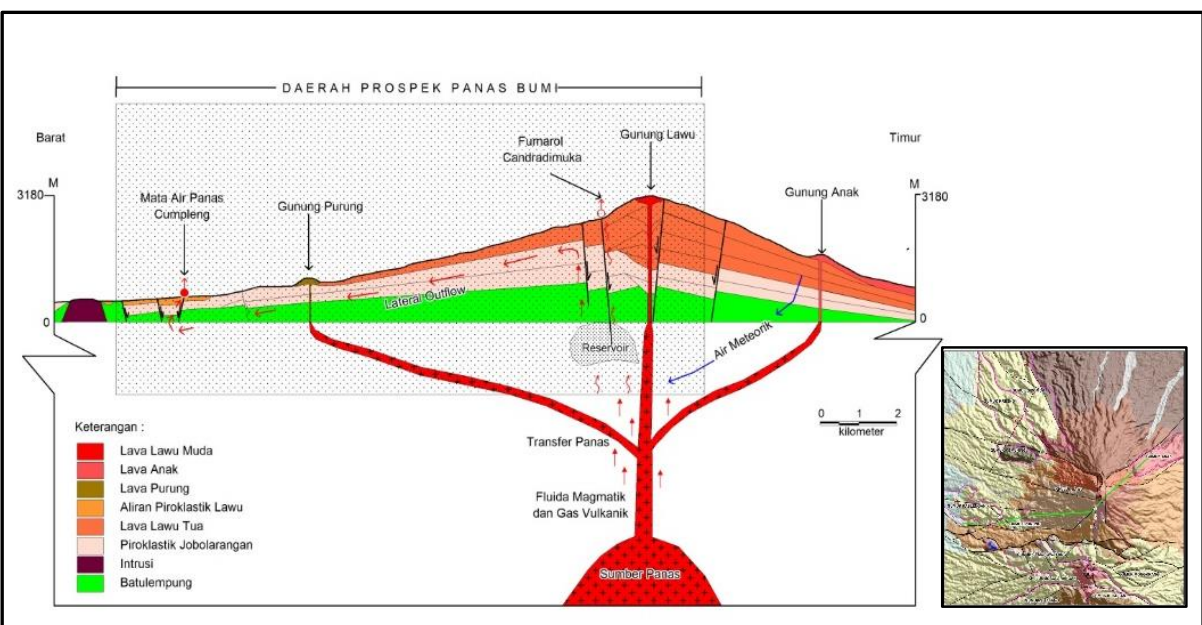

Gambar 10. Penampang vulkanostratigrafi Gunung Lawu dan hubungannya dengan sistem panas bumi Gunung Lawu 


\section{MAKALAH ILMIAH}

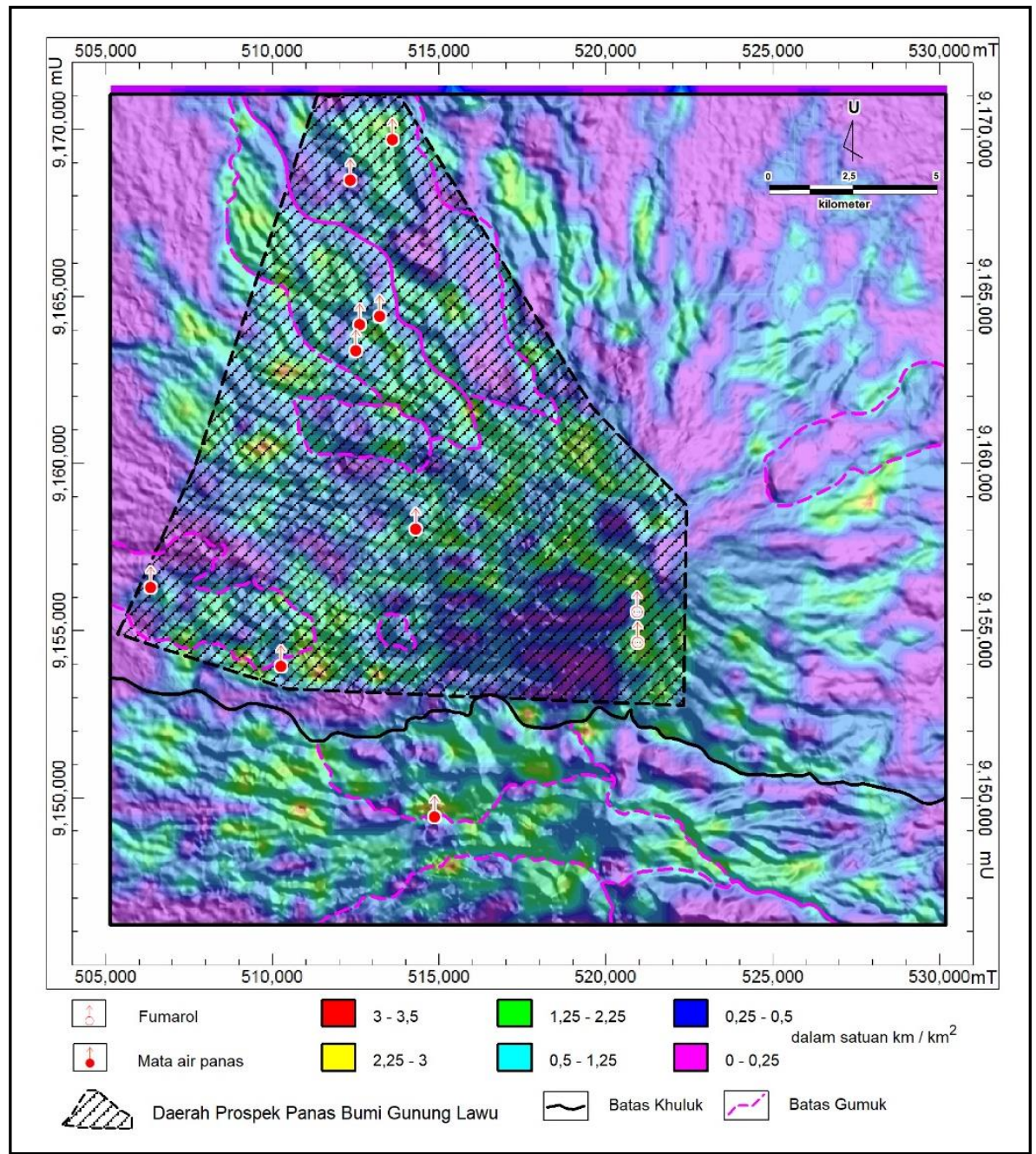

Gambar 11. Peta daerah prospek panas bumi Gunung Lawu

\section{KESIMPULAN}

Kajian karakteristik vulkanik menunjukkan bahwa Gunung Lawu memiliki ukuran atau volume cukup besar, yang mengindikasikan adanya suatu volume magma yang cukup besar di kedalaman dengan fungsi sebagai penyuplai panas dalam sistem panas bumi. Umur vulkanisme termuda Gunung Lawu berada dalam kisaran umur ideal, sehingga panas yang ditransfer dapat membentuk suatu sistem panas bumi yang matang (mature). Selain itu intensitas kerapatan patahan dan rekahan yang tinggi juga memungkinkan terbentuknya suatu zona permeabilitas yang baik sebagai zona reservoir. Hal ini didukung juga oleh luasnya sebaran manifestasi panas bumi seperti pemunculan manifestasi fumarol dan mata air panas, serta batuan ubahan.

Dengan karakteristik tersebut, maka daerah panas bumi Gunung Lawu diperkirakan memiliki prospek panas bumi yang menarik untuk dikembangkan dan perlu diteliti lebih lanjut, terutama pada lereng selatan dan barat Gunung Lawu.

\section{UCAPAN TERIMA KASIH}

Ucapan terima kasih kami ucapkan kepada rekan-rekan di Pusat Sumber Daya Mineral Batubara dan Panas Bumi yang telah memberikan masukan, dan tim editor/reviewer yang telah mengoreksi dan memberikan saran dalam penyusunan makalah ini. Serta kepada dewan redaksi yang telah memberikan kesempatan sehingga makalah ini dapat diterbitkan. 


\section{DAFTAR PUSTAKA}

Alessandro, P., Amatullah, B., Asnin, SN., Regandara, R., Azka, G., Hermawan, D., Prihadi, AS., 2013. Geothermal Potential of Mount Malabar Based on Volcanostratighraphy Study, Proceedings ITB International Geothermal Workshop, 2013.

Anonim, 1996. Sandi Stratigrafi Indonesia Edisi 1996. Jakarta: |AG|

Anonim, 2009. Laporan Survei Terpadu Geologi dan Geokimia Daerah Gunung Lawu, Provinsi Jawa Tengah dan Jawa Timur, Pusat Sumber Daya Geologi, Bandung (unpublished report)

Hermawan, Dudi., dan Rezky, Yuanno., 2011. Delineasi Daerah Prospek Panas Bumi Berdasarkan Analisis Kelurusan Citra Landsat Di Candi Umbul Telomoyo, Provinsi Jawa Tengah, Buletin Sumber Daya Geologi Volume 6 No13-2011 ISSN 1907-5367).

http://srtm.csi.cgiar.org, diakses tanggal 29 November 2017.

Hulen and Anderson., 1998. The Awibengkok, Indonesia, Geothermal Research Project, Proceedings Twenty-third Workshop on Geothermal Reservoir Engineering, Stanford University, Stanford, California.
Hung LQ, Batelaan O, De Smedt F. 2005. Lineament Extraction and Analysis, comparison of Landsat ETM and ASTER imagery. Case study : Suoimuoi Tropical Karst Catchment, Vietnam. Proceedings of SPIE Vol. 5983.

Soetoto, 1996. Interpretasi Citra untuk Survei Geologi, PUSPICS, Fakultas Geografi, Universitas Gadjah Mada, Yogyakarta.

Soengkono, S., 1999. Analysis of Digital Topographic Data for Exploration and Assessment of Geothermal System, Proceeding 21st New Zealand Geothermal Workshop (1999b).

Sumintadireja, P., 2005. Vulkanologi dan Geotermal. Departemen Teknik Geologi, Fakultas IImu Kebumian dan Teknologi Mineral, Institut Teknologi Bandung.

Van Zuidam, R.A. 1985. Aeral Photo Interpretation in Terrain Analysis and Geomorphological Mapping. Smits Publisher, The Hague.

Wohletz, Kenneth dan Heiken, Grant. 1992. Volcanology and Geothermal Energy. Los Angeles : University of California Press.

\begin{tabular}{|ll|}
\hline Diterima & $:$ 29 Oktober 2018 \\
Direvisi & $: 9$ September 2018 \\
Disetujui & $:$ 30 November 2018 \\
\hline
\end{tabular}

